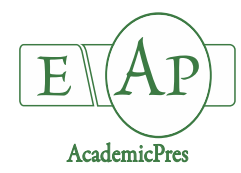

Xie M-M et al. (2020)
Notulae Botanicae Horti Agrobotanici Cluj-Napoca
DOI:10.15835/nbha48312055
Review Article

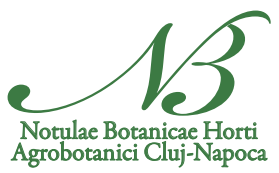

\title{
A friendly-environmental strategy: application of arbuscular mycorrhizal fungi to ornamental plants for plant growth and garden landscape
}

\author{
Miao-Miao XIE ${ }^{1}$, Yu WANG ${ }^{1}$, Qiu-Shuang LI $^{1}$, Kamil KUČA², \\ Qiang-Sheng WU ${ }^{1,2 *}$
}

\author{
${ }^{I}$ Yangtze University, College of Horticulture and Gardening, Jingzhou, Hubei 434025, China; $972948575 @ q q . c o m$; \\ 354274953@qq.com;2357801662@qq.com; wuqiangsh@163.com (*corresponding author) \\ ${ }^{2}$ University of Hradec Kralove, Faculty of Science, Department of Chemistry, Hradec Kralove 50003 , \\ Czech Republic; kamil.kuca@uhk.cz
}

\begin{abstract}
The demand for ornamental plants is increasing due to urban greening and rural construction, while the growing environment of plants, especially the soil environment, is deteriorating. Hence, sustainable methods of ornamental plant cultivation need to be developed quickly. The application of arbuscular mycorrhizal fungi (AMF) to ornamental plants can be one of the eco-friendly ways to achieve the objective. Soil AMF establish mycorrhizal symbiosis with roots of ornamental plants, which can develop a marvelous mycorrhizal mycelium network in the rhizosphere to stimulate nutrient and water acquisition of host plants. Numerous researches have proven that AMF improved the quality of ornamental plants, like fruit yield, height, biomass, seed quality, the size and number of flowers, leaf, and root. In addition, mycorrhizal fungi also improve nutrient uptake and endogenous hormone balance of host plants. Another important function of AMF is to regulate the physiological, biochemical, and molecular responses of host plants to adversity, including drought stress, temperature stress, heavy-metal stress, and insect and disease stress. From the perspective of the ecological garden landscape, AMF richness would maintain plant abundance, nutrient and energy balance, and higher productivity in normal and soil environment stress, thus, establishing a friendly-environmental ecosystem. This review also provides the basis to exploit and improve the commercial application of AMF in ornamental plants in the future.
\end{abstract}

Keywords: endophytic fungi; ecological reconstruction; garden plants; stress; symbiosis

\section{Introduction}

As far as 19 centuries, arbuscular mycorrhizal fungi (AMF) were found to be symbiotic with roots of terrestrial plants in nature for establishing arbuscular mycorrhiza (AM) (Zhang et al., 2020). AM symbiosis can enhance the photosynthetic efficiency of the host to improve shoot and root biomass, roots number and size, flowering, and other morphological indexes (Xie et al., 2018; Li et al., 2020). AMF are important for increasing the uptake of water and nutrients for plant growth and development by a mycorrhizal hyphal network that can 
be expanded the absorptive area by 40 times and explore deeper water and nutrients (Giovannetti et al., 2001; Hayashi et al., 2018; Zhang et al., 2019a). Similarly, AMF regulate endogenous hormone levels to affect plant growth and flowering (Bi et al., 2019). So far, earlier studies have indicated that AMF play one of the most important regulators in plant development in adversity stress. In drought stress, AMF regulate osmotic substances, increase antioxidant enzyme activities, and promote water absorption to enhance drought resistance (Khalvait and Ruth, 2005; Wu et al., 2013; Li et al., 2019). In addition, the presence of AMF alters plant-type, activates the antioxidant defense system, and regulates temperature-related gene expression to alleviate damage by extreme weather (Chen et al., 2013; Zou et al., 2020).

In ornamental plants, according to the variety of mycorrhizal fungi and the characteristics of symbiosis with plants, there are AM, ectotrophic mycorrhiza, orchid mycorrhiza, arbutiod mycorrhiza, ericoid mycorrhiza, and monotropoid mycorrhiza. Hereinto, most of woody and herbaceous plants form AM type. Wood ornamental plants that belong to AM plants include Michelia alba DC., Idesia polycarpa (Figure 1a), Davidia involucrata Baill., Acacia farnesiana (Linn.) Willd., Chimonanthus praecox (Linn.) Link, Osmanthus sp., etc.; Shrub oranmental plants include Cercis chinensis Bunge, Nerium indicum Mill., Camellia japonica L., Hibiscus rosa-sinensis Linn., and so on; and herbaceous ornamental plants include Cymbidium ensifolium Sw.., Rosa chinenses Jacq., Trifolium repens (Figure 1b), Dendranthema morifolium Ram, etc. (Wang et al., 2008). Ornamental plants have different dependence on AMF: Trifolium repens, Rosa chinenses Jacq., and Dendranthema morifolium Ram are the high-dependent on AMF; Matthiola incana (L.) R. Br. and Petunia hybrida Vilm. are the moderate dependent type; Nicotiana tabacum L. and Solanum lycopersicum L. are the low dependent type (Urcelay et al., 2003). It is documented that AMF are widely distributed in various habitats, e.g., meadows, forests, tropical regions, and frigid regions (Yang et al., 2011). These AMF are varied, dependent on environments, and give different effects on ornamental plants (Brundrett, 2004). For example, A part of ornamental plants are also growing in arid and semi-arid areas for soil remediation, where they usually grow poor soil with a small amount of AMF species (Zhang et al., 2018b). The present review outlined the effects of AMF on ornamental quality, nutrient absorption, endogenous hormone levels, and stress resistance of ornamental plants. And the review conferred the function of AMF on the landscape ecosystem of ornamental plants.

\section{Colonization of AMF in roots of ornamental plants}

As mentioned earlier, many ornamental plants have the root mycorrhizal fungal colonization (Figure 1a, 1b), and the degree of mycorrhizal colonization in ornamental plants is varied, dependent on AMF species and plant species. In Solan district, Himachal Pradesh, India, 15 ornamental flower plants showed the different AMF colonization rate, among the highest colonization rate of Senecio cineraria was $100 \%$, and the lowest in Jacobinea carnea was $14.28 \%$ (Kumar et al., 2012). Possibly, some secondary metabolites contents of host plants, such as flavonoid, can affect spore's germination, and mycelium elongation and branching (Fall et al., 2015). The percentage of AMF colonization in roots is increased with the increase of plant-age. For example, Cryptomeria japonica plants had higher colonization rate in first-order roots of older plants than in younger plants, which is related to $\mathrm{P}$ content and $\mathrm{C} / \mathrm{N}$ ratio, thus, conferring more nutrient acquisition (Hishi et al., 2016). Even in the same plant, the percent of AMF infection shows a dynamic change due to the change of season and soil environment (Kumar et al., 2012). AMF colonization in black locust seedlings was decreased, due to the decline of carbon supplication (Yang et al., 2014a). The illumination intensity affected the AMF colonization rate in Syzygium seedlings, whilst the higher photosynthesis results in more carbohydrates into the fungal partner for fungal growth (Gamage et al., 2004). Therefore, the inoculating time, ornamental plant types, and soil environment are critical factors to ensure the success to faster and better form mycorrhizal symbiosis between AMF and ornamental plants. 

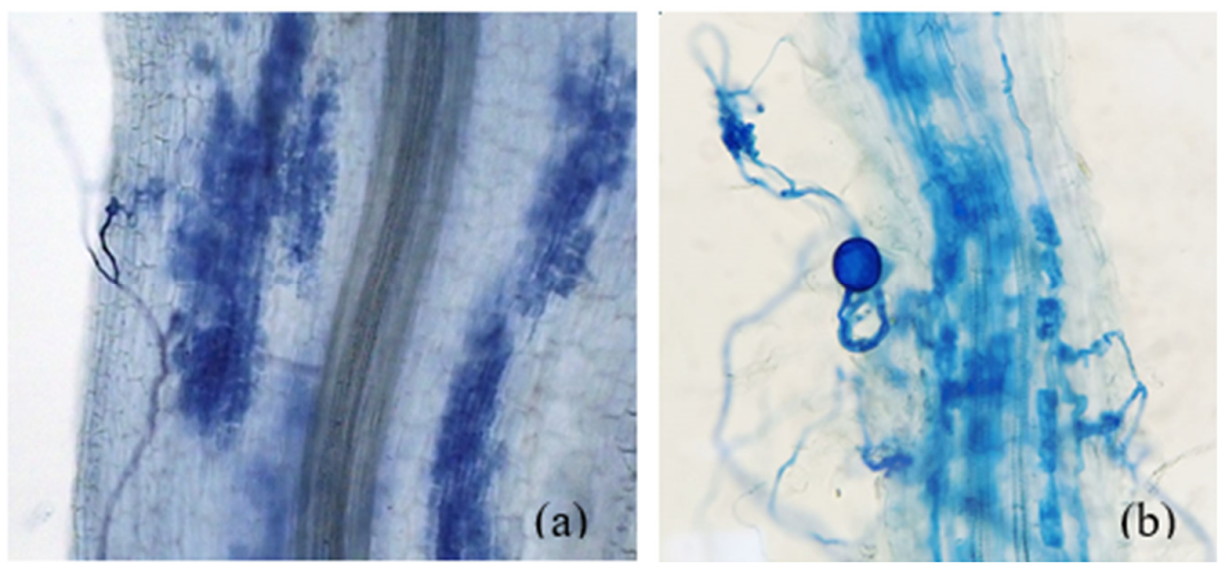

Figure 1. Colonization of arbuscular mycorrhizal fungi in roots of ornamental plants. a: Idesia polycarpa; b: Trifolium repens

\section{AMF effects on ornamental quality of ornamental plants}

There are many paths to improve flowering, growth, and field of ornamental plants, such as temperature, light, and plant growth regulator. However, these paths would be too costly in terms of capital and energy consumption, and long-term use of plant growth regulators harms the soil environment. AMF can be a friendly environmental approach to promote the quality of ornamental plants. Studies indicated that AMF significantly affected flowering, such as the size, the number of flowers, and the phenological stage of flowering (Shamshiri et al., 2012). Comparing with non-AMF plants, AMF-inoculated plants had relatively higher flower number in ornamental plants, such as marigold, geranium, and harlequin (Engel et al., 2016; Varga and Kytöviita, 2010; Scagel, 2004), and also increased size and color in carnation and hyacinth (Navarro et al., 2012; Xie and Wu, 2015; Xie et al., 2018). Similarly, the flowering time of Medicago truncatula was earlier by inoculation with AMF (Liu et al., 2018). The total flowering stage was significantly prolonged in tomato after mycorrhization (Banla et al., 2015), but was shortened in Chrysanthemum morifolium by AMF colonization (Sohn et al., 2003). Garmendia and Manga (2012) reported that inoculation with Glomus mosseae in Rosa hybrida was not significantly affected on early flowering and the number of flowers. The species of AMF have different effects on the flower of host plants and depend on how AMF regulate the nutrient element content in host plants and a certain amount of carbohydrates accumulated in plants (Liu et al., 2018). Similarly, AMF also can directly or indirectly affect the balance of endogenous hormones in plants, thus affecting the growth and flowering of mycorhizal plants. Endogenous hormones, such as indoleacetic acid (IAA), gibberellin (GA), and cytokinin (CTK), are growth-promoting hormones, and are affected by AMF (Perner et al., 2007). And Song et al. (2012) has also proved that inoculation with $G$. intraradices and $G$. mosseaecan significantly enhance the level of IAA, GA and zeatin (ZR) in Amorpha fruticosa. During seed germination, leaf growth, stem elongation, pollen tube elongation, flower and fruit development, and flower transformation, endogenous hormone levels are regulated by AMF for better plant growth responses (Swain and Singh, 2005; Razem et al., 2006). In addition, the hyphae of AMF can produce CTK and GA to effect growth and flowering of ornamental plants (Barea and Azconaguilar, 1982).

AMF do not just change morphological of flower, but also affect inclusion of flower. polyphenol, as an important component of flowering ornament plants, has been affected by AMF in Calendula officinalis, Melissa officinalis, and Origanum majorana (Engel et al., 2016). Not only that, AMF also can influence the quality of ornamental plant progeny by indirectly affecting ornamental plant pollination, AMF alter the seed quality of some Rosaceae by indirectly affecting plant pollination (Barber and Gorden, 2006). AMF increased nectar yield and the male or hermaphrodite flower number and size, to attract pollinators more easily to ensure the formation and quality of progeny seed (Asikainen and Mutikainen, 2005; Kiers et al., 2010; Varga and 
Kytöviita, 2010). At the same time, AMF cause transgenerational effects on the offspring of plants through increasing the proportion of methylated DNA in seed (Varga and Soulsbury, 2017).

Inoculation with $G$. intraradices or Gigaspora albida significantly increased collar diameter and root length in Eucalyptus hybrid (Sastry et al., 2000). In the urban garden, inoculation with AMF had positive effects on total shoot length, trunk diameter, shoot and root biomass, and shoot to root ratio in Acacia smallii and Fraxinus uhdei (Stabler et al., 2001). In addition, root structure was greatly improved by AMF to delay the senescence of Cryptomeria japonica (Hishi et al., 2016). Similarly, the most significant effect of AMF on ornamental grasses is to increase the biomass of shoot and root and the root activity for promoting density and coverage of lawn (Watts-Williams et al., 2019). However, there was no effect on plant height in mycorrhizal tall fescue, while plant height of both eastern gamagrass and big bluestem was positively increased in mycorrhizal plants (Thorne et al., 2013), suggesting that the AMF effect is dependent on host and AMF species. Therefore, when AMF are applied to any ornamental plant, efficient screening of mycorrhizal fungi is required.

\section{Improvement of mineral nutrition in mycorrhizal ornamental plants}

Ornamental plants need adequate industrial chemical fertilizer, which would pollute the soil environment. AMF, a natural biological fertilizer, could not result in environmental pollution. Studies have proven that AMF significantly improved the absorption of nutrient elements, like N, P, and K in mycorrhizal Chrysanthemum morifolium, Petunia hybrida, Tegetes erecta, Callistephus chinensis, Papaver rhoeas, and Dianthus caryophyllus, as well $\mathrm{Fe}, \mathrm{Mn}, \mathrm{Cu}$, and $\mathrm{Zn}$ (Table 1) (Sohn et al., 2003; Gaur and Adholeya, 2005). The nutritional improvement under mycorrhizal is closely related to hyphae of AMF that increases the absorption of nutrient elements. The mycorrhizal hyphae expand the area of absorption of nutrient element, but also increase the ability to absorb nutrient elements (Mathur et al., 2018). The content of N, P, and K was significantly increased in Hyacinthus orientalis L. by inoculation with Funneliformis mosseae, but not Diversispora spurca and D. versiformis (Xie and $\mathrm{Wu}, 2015$ ). In pelargonium, inoculation with AMF significantly increased $\mathrm{P}$ and K content, not $\mathrm{N}$ concentration (Perner et al., 2007). Huang et al. (2020) reported that in walnut (Juglans regia), inoculation with AMF (Acaulospora scrobiculata, D. spurca, G. etunicatum, $G$. mosseae and $G$. versiforme), to some extent, increased root nutrient contents, dependent on AMF species and mineral types. The above results fully indicate that AMF inoculation has a positive effect on nutrient uptake of ornamental plants, which depends on mineral elements, host plants, and AMF species.

It was proved that extraradical mycelium of AMF contribute P requirements for up to $80 \%$ plants (Marschner and Dell, 1994) because the network of hyphae expands the volume of P absorption, but also secretes phosphatases to catalyze organic compounds into phosphate (Hayashi et al., 2018). The gene of $\mathrm{P}$ transporters is up-regulated by AMF to associate $\mathrm{P}$ uptake in many plants (Fellbaum et al., 2014). The expression of MtPT4 was induced by AMF in the root of Medocago truncatula. AMF promote organic and inorganic $\mathrm{N}$ absorption and transportation for host plants by extratradical mycelium, and $\mathrm{NH}_{4}{ }^{+}$is the major form to be absorbed (Leigh et al., 2009). Wang et al. (2020) proved that about $42 \%$ of total $\mathrm{N}$ was obtained via mycorrhizal rice roots under $\mathrm{NO}_{3}$ supply condition, and putative nitrate transporter gene OsNPF4.5 had been strongly induced in rice roots. Especially, the increase of $\mathrm{N}$ nutrient was more obviously in leguminous by AMF, contributed to the nodule number and $\mathrm{N}$ metabolism-related enzyme activity (Xie et al., 2020). A higher $\mathrm{K}^{+} / \mathrm{Na}^{+}$ratio in mycorrhizal Zelkova serrata seedling subjected to salt stress protected protein synthesis and cellular enzymatic processes (Wang et al., 2019a). Paying attention to other nutrients in ornamental plants should be involved. 
Xie M-M et al. (2020). Not Bot Horti Agrobo 48(3):1100-1115

Table 1. Effects of inoculation with AMF on the quality performance of ornamental plants

\begin{tabular}{|c|c|c|c|}
\hline $\begin{array}{l}\text { Ornamental plant } \\
\text { species }\end{array}$ & AMF species & Mycorrhizal effects on ornamental plants & Reference \\
\hline Kinnow & $\begin{array}{l}\text { Glomus manihotis, G. mosseae, } \\
\text { and Gigaspora gigantia }\end{array}$ & $\begin{array}{c}\text { Improving growth parameters like plant height, canopy } \\
\text { volume, mean leaf area, and number of new shoots per plant, } \\
\text { and altering flowering phenology }\end{array}$ & $\begin{array}{l}\text { Shamshiri et al., } \\
2012\end{array}$ \\
\hline $\begin{array}{l}\text { Calendula officinalis, } \\
\text { Melissa officinalis, and } \\
\text { Origanum majorana }\end{array}$ & $\begin{array}{l}\text { Claroideoglomus etunicatum, } \\
\text { C. claroideum and } \\
\text { Rhizophagus intraradices }\end{array}$ & Increasing biomass and polyphenol content & Engel et al., 2016 \\
\hline Geranium sylvaticum & Glomus claroideum and G. hoi & $\begin{array}{l}\text { Improvement of floral diameter, functional stamens, and } \\
\text { pollen grains }\end{array}$ & $\begin{array}{c}\text { Varga and } \\
\text { Kytöviita, } 2010\end{array}$ \\
\hline Sparaxis tricolor & Glomus intraradices & $\begin{array}{l}\text { AMF-inoculated plants blossom 7-9 days earlier and } \\
\text { produced more flowers, croms and biomass per plant }\end{array}$ & Scagel, 2004 \\
\hline D. caryophyllus & Glomus intraradices & Improvemeng in growth, quality and mineral concentrations & $\begin{array}{l}\text { Navarro et al., } \\
2012\end{array}$ \\
\hline Hyacinth & $\begin{array}{c}\text { Diversispora spurca, } D \text {. } \\
\text { versiformis, and Funneliformis } \\
\text { mosseae }\end{array}$ & $\begin{array}{l}\text { Only Funneliformis mosseae increased morphology, color, } \\
\text { and lasting time of flowers, which is related with enhanced } \\
\text { IAA levels and N, P and K concentrations }\end{array}$ & Xie and Wu, 2015 \\
\hline Trifolium repens & $\begin{array}{l}\text { Funneliformis mosseae, } \\
\text { Paraglomus occultum, and } \\
\text { Rhizophagus intraradices }\end{array}$ & $\begin{array}{c}\text { Dual inoculation of Rhizobium trifolii and } P \text {. occultum or } R \text {. } \\
\text { intraradices further magnified the positive effect. Leaf and } \\
\text { root } \mathrm{N} \text { content, root total soluble protein content, root } \\
\text { nitrogenase activity, and amino acid }\end{array}$ & Xie et al., 2018 \\
\hline Rosa hybrida & $\begin{array}{c}\text { Glomus intraradices and } G . \\
\text { mosseae }\end{array}$ & $\begin{array}{l}\text { No change in plant biomass, leaf nutritional status and flower } \\
\text { quality of rose after inoculation with AMF, due to low } \\
\text { symbiosis establishment }\end{array}$ & $\begin{array}{l}\text { Garmendia and } \\
\text { Manga, } 2012\end{array}$ \\
\hline $\begin{array}{l}\text { Pelargonium peltatum } \\
\text { L'Her. }\end{array}$ & $\begin{array}{l}\text { Three different commercially } \\
\text { available inocula }\end{array}$ & $\begin{array}{l}\text { Mycorrhizal colonization increased the number of buds and } \\
\text { flowers, as well as shoot } \mathrm{P} \text { and potassium }(\mathrm{K}) \text { concentrations, } \\
\text { but did not significantly affect shoot dry matter or shoot } \mathrm{N} \\
\text { concentration }\end{array}$ & Perner et al., 2007 \\
\hline Amorpha fruticosa & $\begin{array}{l}\text { Glomus intraradices and } G \text {. } \\
\text { mosseae }\end{array}$ & $\begin{array}{l}\text { the seedlings' growth indexes, dynamic characteristics of } \\
\text { plant endogenous hormone levels, soluble sugar contents in } \\
\text { roots and in leaves respectively, and nitrogen }(\mathrm{N}) \text {, } \\
\text { phosphorous }(\mathrm{P}) \text { were significantly increased by AMF }\end{array}$ & Song et al., 2012 \\
\hline $\begin{array}{l}\text { Calendula officinalis, } \\
\text { Melissa officinalis, } \\
\text { Origanum majorana }\end{array}$ & $\begin{array}{l}\text { Claroideoglomus etunicatum, } \\
\text { C. claroideum, and } \\
\text { Rhizophagus intraradices }\end{array}$ & $\begin{array}{l}\text { AMF inoculation significantly increased the biomass of } \\
\text { marjoram, the number of marigold's flowers and the yield of } \\
\text { rosmarinic acid and lithospermic acid isomers of marjoram } \\
\text { and lemon balm. }\end{array}$ & Engel et al., 2016 \\
\hline Medicago truncatula & $\begin{array}{c}\text { Acaulospora scrobiculata, } \\
\text { Gigaspora margarita, } \\
\text { Funneliformis geosporum, } \\
\text { Rhizophagus intraradices, F. } \\
\text { mosseae, and Glomus } \\
\text { tortuosum, }\end{array}$ & $\begin{array}{c}\text { Inoculation with Funneliformis geosporum, Glomus } \\
\text { tortuosum, or Acaulospora scrobiculata had two periods of } \\
\text { rapid flower production }\end{array}$ & Liu et al., 2018 \\
\hline Geranium sylvaticum & $\begin{array}{l}\text { Claroideoglomus claroideum } \\
\text { and Glomus hoi }\end{array}$ & Higher DNA methylation & $\begin{array}{c}\text { Varga and } \\
\text { Soulsbury, } 2017\end{array}$ \\
\hline Eucalyptus hybrid & $\begin{array}{l}\text { Acaulospora scrobiculata, } \\
\text { Gigaspora albida, and Glomus } \\
\text { intraradices }\end{array}$ & $\begin{array}{l}\text { Glomus intraradices or Gigaspora albida significantly } \\
\text { increased collar diameter, root length and shoot length. }\end{array}$ & Sastry et al., 2000 \\
\hline $\begin{array}{l}\text { Acacia smalii, Fraxinus } \\
\text { uhdei, and Parkinsonia } \\
\text { microph }\end{array}$ & $\begin{array}{l}\text { Acaulospor morrowiae, } \\
\text { Glomus ebumeum, } G \text {. } \\
\text { facisculatum, } G \text {. } \\
\text { miaoaggmgatum, and } G \text {. } \\
\text { mosseae }\end{array}$ & $\begin{array}{c}\text { Increase in total shoot length, trunk caliper, total dry weight, } \\
\text { shoot dry weight, root dry weight, shoot to root ratio, and } \\
\text { phosphorus concentration in Acacia smallii and Fraxinus } \\
\text { uhdei }\end{array}$ & Stabler et al., 2001 \\
\hline Cryptomeria japonica & $\begin{array}{l}\text { Various mycorrhizal fungi in } \\
\text { foreste }\end{array}$ & $\begin{array}{l}\text { Improvement in root structure, especially fine roots, and } \\
\text { delaying of plant senescence }\end{array}$ & Hishi et al., 2016 \\
\hline Medicago truncatula & Funneliformis mosseae & $\begin{array}{l}\text { Increase in biomass, shoot nutrient concentrations, and root } \\
\text { activity and inducation of } M t A Q P 1 M t P I P 1, M t P I P 2, \\
M t N I P 1 \text {, and } M t N I P 4 \text { expression under drought stress }\end{array}$ & $\begin{array}{l}\text { Watts-Williams et } \\
\text { al., } 2019\end{array}$ \\
\hline $\begin{array}{c}\text { Tall fescue, Big } \\
\text { bluestem, and Eastern } \\
\text { gamagrass }\end{array}$ & $\begin{array}{l}\text { Sources of AMF from Claridon } \\
\text { and Wilds }\end{array}$ & $\begin{array}{l}\text { Tall fescue was not affected by AMF, while plant growth of } \\
\text { big bluestem and eastern gamagrass was enhanced }\end{array}$ & $\begin{array}{l}\text { Thorne et al., } \\
2013\end{array}$ \\
\hline
\end{tabular}




\section{Enhancement of stress resistance in ornamental plants by AMF Drought stress}

Researches have confirmed that AMF significantly enhanced drought resistance in ornamental plants (Wu et al., 2013, 2019; Zhang et al., 2020). AMF usually improved the root structure of ornamental plants, such as root number, length, surface area, and diameter (Wu et al., 2013). The great root system obtains more water in wider and deeper soil, but also allow more abundant extraradical hyphae of AMF, which are much thinner than fine roots, to expand beyond depletion zone and penetrate smaller pores to absorb water and nutrient (Allen, 2011; Smith and Smith, 2011; Zhang et al., 2018a; Zou et al., 2020). Meanwhile, Khalvait and Ruth (2005) indicated that $4 \%$ of water was transported to the roots of host plants by hyphae. And the hyphae increase the total water absorption rate by $20 \%$ (Ruth et al., 2011). Therefore, mycorrhizal ornamental plants improve drought tolerance, which attributes to the increase of hydraulic conductivity (Robert et al., 2008). Mycorrhizal ornamental plants can maintain higher water-use efficiency and relative water content than nonAMF plants (Yang et al., 2014b), providing favorable condition for accumulation of carbohydrates and gas exchange (Zhu et al., 2012). Under soil water deficit, mycorrhizal plants remarkably increase the accumulation of carbon compounds to respond to oxidative burst (Barros et al., 2018). In addition, AMF induce antioxidant defense systems to mitigate the accumulation of reactive oxygen species in mycorrhizal plants (Zou et al., 2020). Li et al. (2019) showed that AMF reduced malondialdehyde content, increased catalase and superoxide dismutase activity in Leymus chinensis under water stress. Furthermore, AMF can AMF regulate the expression of drought-related genes in plants (Cheng et al., 2020a). Two functional aquaporin genes from $G$. intraradices, GintAQPF1 and GintAQPF2, were expressed strongly in cortical cells with rich intraradical mycelia and extraradical mycelia of roots under drought stress (Li et al., 2013). However, host $A Q P s$ were down-regulated or unchanged by AMF inoculation under drought stress (Zou et al., 2019). Hence, Cheng et al. (2020a) proposed the synergistic effect of host and fungal $A Q P s$ on water status of hosts. AMF are involved in the induced expression of P5CS genes encoding a rate-limiting enzyme in proline synthesis (Porcel et al., 2004) and NCED genes encoding a key enzyme in ABA synthesis during drought stress and recovery (Aroca et al., 2008). Hence, mycorrhizal ornamental plants have a greater capacity to tolerate drought stress by a series of physiological and molecular mechanisms.

\section{Temperature stress}

In recent years, extreme weather is happening with increasing frequency by global climate change. Ornamental plants are always subjected to low- or high-temperature stress. AMF help plant responses to stress by altering plant physiological activities (Duhamel et al., 2013), Thus, inoculation with AMF maybe be an efficient strategy to cope with low and high temperature through promoting nutrient absorption, changing cell membrane structure, activating the antioxidant system, and regulating temperature-related gene expression (Tu et al., 2019). Bunn et al. (2009) had proven that AMF showed better heat tolerance than roots, with the increasing temperature. Under high-temperature soil, Dichanthelium lanuginosm plants inoculated with AMF significantly increased plant biomass, root length and diameter, and proportion of flowers and promoted early flowering (Bunn et al., 2009). Five AMF species collectively promoted shoot and root biomass, and reduced indices of leaf and root browning in strawberry under high-temperature stress, and $G$. mosseae and $G$. aggregatum had most effective (Matsubara et al., 2004). Additionally, mycorrhizal plants hold higher photosynthetic capacity and avoid the damage to the photosynthetic apparatus under high temperature (Mathur et al., 2020). Under low temperature stress, Ornithopus compressus and Lolium rigidum inoculated with AMF significantly increased plant growth than non-AMF plants (Carvalho et al., 2015). That could be AMF inoculation stimulated cyclic electron flow process in chloroplasts to reduce damage of stress, but also affected electrons transmission and phosphoric acid production in mitochondria, thus, promoting carbon metabolism under temperature stress (Mathur et al., 2020). Simultaneously, AMF induced the cold-tolerant gene expression of the host, and twenty-four DEGs identified were associated with the metabolism of photosynthesis and respiratory (Li et al., 2020). AMF increased secondary metabolites content and antioxidant 
enzyme activities, and induced expression of stress-related genes under low temperature (Chen et al., 2013). Therefore, mycorrhizal fungi are an important protocol for ornamental plants to resist temperature stress, which should be paid more attention.

\section{Heavy-metal stress}

In cities, a large amount of ornamental plants is planted in soil polluted by heavy metals, which severely limits plant growth and survival. Fortunately, AMF have been considered as a cost-effective and environmentally friendly protocol in phytoremediation and ecological restoration (Yang et al., 2015b). Elsholtzia splendens applied to a Cu-contaminated soil that significantly delayed the first-flowering dates and full-bloom stage and shorted flowering duration without AMF, whereas AMF recovered it and even promoted the flowering period (Jin et al., 2015). Generally, mycorrhizal hyphae and spores of AMF combine with heavy metal ions to reduce their mobility in the soil (Janoušková and Pavlíková, 2010). The hyphae also decrease the distribution of heavy metal from root to leaf, protect leaf tissues from injury (Yang et al., 2015a; Kushwaha et al., 2016). Similarly, Zhou et al. (2017) adopted a spectrum to analyze $\mathrm{Cu}$ content at the cross section of root tip of Tagetes patula, and confirmed that intraradical hyphae could selectively sequestrate a great deal of free $\mathrm{Cu}$ through sorption and barrier mechanisms. In general, soil nutrients are always low under excessive heavy metals condition, while mycorrhizal ornamental plants usually maintain higher nutrient levels. For example, mycorrhizal Medicago sativa had higher biomass and N, P, K and Ca contents than non-mycorrhizal plants under Cd stress (Zhang et al., 2019b). AMF also secrete a special glycoprotein, glomalin, to contribute soil nutrient pools and form protein-metal compounds for reducing the level of heavy metal in soil (Chern et al., 2007; Gonzalez-Chavez et al., 2009; He et al., 2020; Meng et al., 2020). Inoculation with Funneliformis mosseae enhanced the levels of $A T P$ binging cassette $(A B C)$ and metallothioneins $(M E T)$, transcripts in tall fescue roots under Ni stress (Shabani et al., 2016). Thereinto, Gint $A B C 1$ isolated from extraradial mycelium of $G$. intraradices, participated in reducing toxicity of $\mathrm{Cu}$ and $\mathrm{Cd}$ (González-Guerrero et al., 2010). Furthermore, Rint $Z n T 1$, a $\mathrm{Zn}$ transporter, participated in isolation of $\mathrm{Zn}$ in vacuolar (González-Guerrero et al., 2005). Therefore, an important research hotspot of mycorrhizas in ornamental plants is the mechanism of heavy metal pollution soil adaptive to mycorrhizal fungi in ornamental plants.

\section{Diseases and insect}

AMF affect the population of pathogenic microbes and harmful rhizospheric pests (Cheng et al., 2020b). Slezack et al. (1999) discovered that inoculation with Glomus mosseae significantly reduced the red rot of pea roots by Aphanomyces euteiches. The date palm (Phoenix dactylifera L.) against inoculated with AMF reduced the index of pathogen occurrence by $8-77 \%$ (Jaiti et al., 2007). The mechanisms of AMF on enhancing the tolerance of diseases and insects is due to the competition between AMF and pathogens and insect for rhizospheric microbes, colonization sites, and nutrient substances (Al-Aska et al., 2010). Perhaps AMF compensate the damage of diseases and insect through improvement of plant health, root structure, and nutrient acquisition (Majewska et al., 2017). However, there was no significant difference between $G$. intraradices-colonized plants and non-AMF-colonized plants infected with white rot (Prados-Ligeo., 2002). AMF also inhibited the damage of nematode in menthol mint (Ratti et al., 2000), and reduced the damage of Pratylenchus coffea (Elsen et al., 2003). Additionally, many genes (ChtA3, gluB, CEVI16, OSM-8e and PR-1) have been predicted to participate in defense responses to enhance the disease resistance of mycorrhizal plants via transcript profiles (Liu et al., 2007; Ismail and Hijri, 2012).

As a whole, when ornamental plants grow in poor soil, inoculation with AMF not only increases the adaptability of ornamental plants to adversity but also improves the soil environment, which will be beneficial to the further application of ornamental plants in urban greening. 


\section{AMF and ecological garden landscape}

Ornamental plants are frequently used in the ecological garden that is distributed in urban green space, rural area, and a damaged environment land. A higher richness of community productivity is found in the ecological system with various ornamental plants than in a conventional system (Lacombe et al., 2009). It is well-known that the interaction between plant and microbial communities affects the balance of biodiversity and ecosystem function (Klironomos et al., 2011). AMF are the vital component of the underground biome and widely distributed in various eco-systems with kinds of plants (Lee et al., 2013). In addition, AMF directly affect the performance of host plants and indirectly affect plant communities via the increase of nutrient absorption and availability of soil nutrients by underground mycorrhizal networks (Werner et al., 2015). In contrast, the diversity and richness of host plants also affect AMF communities, which could give priority to providing carbon to beneficial symbionts (Vogelsang et al., 2006). AMF have effect on a variety of ecosystem functions by various pathways. Perhaps AMF are ubiquitous in terrestrial ecosystems and have a greater effect in the ecosystem than other soil microbes, like phosphate-solubilizing bacteria and nitrifiers (Powell et al., 2018). Additionally, AMF have positive effects on soil microorganism population and soil physical and chemical properties, which benefit the ecological restoration (Yang et al., 2016b). Hereinto, AMF reduce water loss of soil and soil hydrophobicity by AMF-released glomalin, resulting in low soil erosion in mycorrhizal soils (Rillig, 2004; Rillig et al., 2010).

Urban ecological landscapes are usually built on developed construction sites, including urban garden, residential landscape, and road afforesting, with a very small number of microbial species. Ornamental plants could be colonized by AMF in urban environments, but the propagule abundance or infectivity is relatively lower than the natural environment (Wisemanand Wells, 2005). Plenty of ornamental plants are applied to the urban ecological garden landscape by tree transplanting, while the plant survival rate is dramatically low under such poor ecological conditions. Dag et al. (2009) indicated that AMF promoted olive transplanting with higher height, shoot and root biomass, and leaf and root nutrient levels without fertilization to increase tolerance of transplant shock. The AMF species richness and communities are dependent on ornamental plant species (Wang et al., 2019b). Therefore, the combination with ornamental plants and appropriate AMF community built wonderful garden ecosystems that have less interspecific competition, better water and nutrient levels, and greater tolerance of abiotic and biotic stress (Teste et al., 2017).

Ornamental plants often apply to build beautiful rural, which need to be in line with the local natural conditions. Unlike urban environment, the rural environment has higher species diversity, organisms' number, and total biomass (Bainard et al., 2011). Therefore, exotic ornamental plants are difficult to blend into the local rural ecology without causing a threat by changing native plant species, community composition, and ecological functions (Aerts et al., 2017). The richness and composition of AMF indirectly influence plant survival and establish in an unfamiliar environment (Yang et al., 2014a; Lin et al., 2015). When exotic ornamental plants are introduced into a new environment, the native AMF from rhizosphere of the exotic plants must be introduced to increase the plant survival rate and growth (Egidi et al., 2018; Policelli et al., 2019). Hence, it is necessary to know AMF diversity in the native and new habitat. In some cases, exotic plants and AMF can overcome the lack of AMF group, and the native AMF are crucial for the transplanting of ancient trees (Sulzbacher et al., 2018). However, indigenous AMF may cause ecological risks in the new environment, which needs to be noted (Davison et al., 2015).

Possibly, ornamental plants in ecological landscapes cannot be used to remediate the terrible soil environment, such as the soil with heavy metal, pesticide residue, and organic pollutant, but they beautify the polluted environment. AMF as an effective protocol can be considered to apply soil remediation (Joner et al., 2001). Yang et al. (2016a) showed that AMF strengthened nutrient complementarities between plants through an underground mycorrhizal hyphal network. Similarly, under hydrocarbon-contaminants soil, AMF colonization promoted the absorption of polycyclic aromatic hydrocarbon, and AMF also degraded organic pollutants in the soil (Singer et al., 2003; Rajtor and Piotrowskaseget, 2016). AMF species and number in the ecosystem having multiple plants are relatively higher than those in the ecosystem with a single plant, and thus 
an ecosystem of diverse plant species with abundant AMF diversity has more glomalin released from AMF to chelate heavy metals in the soil (Bedini et al., 2010).

\section{Conclusions}

At present, the beneficial effects of AMF are confirmed in ornamental plants with better plant growth performance, more nutrient acquisition, and higher resistance to stress (Figure 2). AMF play a vital role in the establishment and maintenance of the ecological landscape in various soil environments. In the future, more applied studies should be carried out as soon as possible to make AMF commercially available. However, there are still many problems to be solved before the AMF can be used:

i) There is no qualitative breakthrough in AMF propagation in vitro. Large-area application of AMF on ornamental plants requires a lot of mycorrhizal inoculums. Therefore, the development of economic, reliable, and efficient protocol for AMF propagation still needs to be paid attention;

ii) AMF promote flowering and improve the ornamental quality of ornamental plants, while the underlying mechanism at the molecular level is still unclear and needs to be researched.

iii) When exogenous AMF are applied to the rhizosphere of ornamental plants, the biological risk must be concerned, so as not to destroy the community of indigenous AMF.

iv) The effect of AMF on ornamental plants depends on their compatibility. Therefore, an effective evaluation system of AMF for ornamental plants should be established to screen effective AMF to early apply it in the nursery.

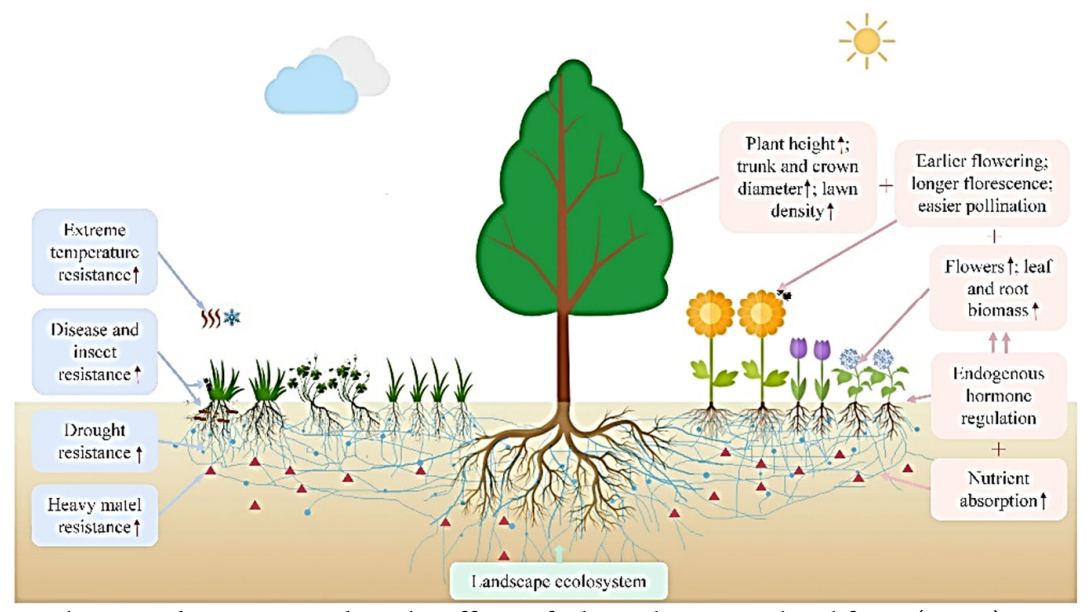

Figure 2. A schematic diagram regarding the effects of arbuscular mycorrhizal fungi (AMF) on ornamental plants and their rhizosphere for establishing and maintaining landscape ecosystem. AMF colonize the root system of an ornamental plant, establish a developed extraradical mycelium network, and further colonize the neighboring plants. Therefore, the developed mycelium network establishes the plants in an ecosystem as an organic whole. These mycorrhizal networks and extracellular mycelium help ornamental plants that grow better and have better nutrients and resistance of abiotic and biotic stress. Therefore, AMF can be used as an environmentally friendly medium to construct garden landscape.

( Insect; $\bullet$ Disease; Extraradical hyphae; Spore; $\Delta$ Heavy metal pollution) 


\section{Authors' Contributions}

Conceptualization: MMX and QSW; Data curation: MMX, YW and QSW; Formal analysis: MMX, QSW and KK; Funding acquisition: QSW; Investigation: MMX; Project administration: QSW; Supervision: QSW; Writing - original draft: MMX; Writing -review and editing: QSW and KK. All authors read and approved the final manuscript.

\section{Acknowledgements}

This study received the support of the project of Hubei Agricultural Science and Technology Innovation Action Plan, Hubei Provincial Department of Agriculture, China (E Nongfa [2018] 1).

\section{Conflict of Interests}

The authors declare that there are no conflicts of interest related to this article.

\section{References}

Aerts R, Ewald M, Nicolas M, Piat J, Skowronek S, Lenoir J, ... Schmidtlein S (2017). Invasion by the alien tree Prunus serotina alters ecosystem functions in a temperate deciduous forest. Frontiers in Plant Science 8:179-187. https://doi.org/10.3389/fpls.2017.00179

Aroca R, Vernieri P, Ruiz-Lozano JM (2008). Mycorrhizal and non-mycorrhizal Lactuca sativa plants exhibit contrasting responses to exogenous ABA during drought stress and recovery. Journal of Experimental Biology 59:2029-2041. https://doi.org/10.1093/jxb/ern057

Asikainen E, Mutikainen P (2005). Preferences of pollinators and herbivores in gynodioecious Geranium sylvaticum. Annals of Botany 95:879-86. https://doi.org/10.1093/aob/mci094

Bainard LD, Klironomos JN, Gordon AM (2011). The mycorrhizal status and colonization of 26 tree species growing in urban and rural environments. Mycorrhiza 21(2):91-96. https://doi.org/10.1007/s00572-010-0314-6

Banla EM, Banito A, Sogbedji JM (2015). Effects of arbuscular mycorrhizal fungi on the production of tomato in Togo. International Journal of Biological and Chemical Sciences 9(3):1270-1276. https://doi.org/10.4314/ijbcs.v9i3.12

Barber NA, Gorden NL (2015). How do belowground organisms influence plant-pollinator interactions?. Journal of Plant Ecology 8(1):1-11. https://doi.org/10.1093/jpe/rtu012

Barea JM, Azconaguilar C (1982). Production of plant growth-regulating substances by the vesicular-arbuscular mycorrhizal fungus Glomus mosseae. Applied and Environmental Microbiology 43(4):810-813. https://doi.org/10.1128/aem.43.4.810-813.1982

Barros V, Frosi G, Santos M, Ramos DG, Falcao HM, Santos M (2018). Arbuscular mycorrhizal fungi improve photosynthetic energy use efficiency and decrease foliar construction cost under recurrent water deficit in woody evergreen species. Plant Physiology and Biochemistry 3:469-477. https://doi.org/10.1016/j.plaphy.2018.04.016

Bedini S, Turrini A, Rigo C, Argese E, Giovannetti (2010). Molecular characterization and glomalin production of arbuscular mycorrhizal fungi colonizing a heavy metal polluted ash disposal island, downtown Venice. Soil Biology and Biochemistry 42(5):758-765. https://doi.org/10.1016/j.soilbio.2010.01.010

Bi Y, Zhang J, Song Z, Wang ZG, Qiu L, Hu JJ, Gong YL (2019). Arbuscular mycorrhizal fungi alleviate root damage stress induced by simulated coal mining subsidence ground fissures. Science of the Total Environment 652:398405. https://doi.org/10.1016/j.scitotenv.2018.10.249

Bunn RA, Lekberg Y, Zabinski CA (2009). Arbuscular mycorrhizal fungi ameliorate temperature stress in thermophilic plants. Ecology 90(5):1378-1388. https://doi.org/10.1890/07-2080.1 
Carvalho MD, Brito I, Alho L, Goss MJ (2015). Assessing the progress of colonization by arbuscular mycorrhiza of four plant species under different temperature regimes. Journal of Plant Nutrition and Soil Science 178(3):515-522. https://doi.org/10.1002/jpln.201400303

Chen S, Jin W, Liu A, Zhang S, Liu D, Wang F, ... He C (2013). Arbuscular mycorrhizal fungi (AMF) increase growth and secondary metabolism in cucumber subjected to low temperature stress. Scientia Horticulturae 160:222-229. https://doi.org/10.1016/j.scienta.2013.05.039

Cheng HQ, Ding YE, Shu B, Zou YN, Wu QS, Kuča K (2020a). Plant aquaporin responses to mycorrhizal symbiosis under abiotic stress. International Journal of Agriculture and Biology 23:786-794. https://doi.org/10.17957/IJAB/15.1353

Cheng S, Tian L, Zou YN, Wu QS, Kuca K, Bora P (2020b). Molecular responses of arbuscular mycorrhizal fungi in tolerating root rot of trifoliate orange. Notulae Botanicae Horti Agrobotanici Cluj-Napoca 48(2):558-571. https://doi.org/10.15835/nbha48211916

Chern EC, Tsai DW, Ogunseitan OA (2007). Deposition of glomalin-related soil protein and sequestered toxic metals into watersheds. Environment Science and Technology 41(1):3566-3572. https://doi.org/10.1021/es0628598

Dag A, Yermiyahu U, Ben-Gal A, Zipori I, Kapulnik Y (2009). Nursery and post-transplant field response of olive trees to arbuscular mycorrhizal fungi in an arid region. Crop and Pasture Science 60(5):427-433. https://doi.org/10.1071/CP08143

Davison J, Moora M, Öpik M, Adholeya A, Ainsaar L, Bâ A, ... Jairus T (2015). Global assessment of arbuscular mycorrhizal fungus diversity reveals very low endemism. Science 349:970-973. https://doi.org/10.1126/science.aab1161

Duhamel M, Vandenkoornhuyse P (2013). Sustainable agriculture: possible trajectories from mutualistic symbiosis and plant neodomestication. Trends in Plant Science 18:597-600. https://doi.org/10.1016/j.tplants.2013.08.010

Egidi E, Franks AE (2018). Incorporating fungal community ecology into invasion biology: challenges and opportunities. Microbiology Australia 8:56-60. https://doi.org/10.1071/MA18015

Elsen A, Baimey H, Sweenen R, De Waele D (2003). Relative mycorrhizal dependency and mycorrhiza-nematode interaction in banana cultivars (Musa spp.) differing in nematode susceptibility. Plant and Soil 256:303-313. https://doi.org/10.1023/A:1026150917522

Engel R, Szabo K, Abranko L, Rendes K, Fuzy A, Takacs T (2016). Effect of arbuscular mycorrhizal fungi on the growth and polyphenol profile of marjoram, lemon balm, and marigold. Journal of Agricultural and Food Chemistry 64:3733-3742. https://doi.org/10.1021/acs.jafc.6b00408

Fall F, Diouf DEG, Fall D, Ndoye I, Ndiaye C, Kane A, Ba AM (2015). Effect of arbuscular mycorrhizal fungal inoculation on growth, and nutrient uptake of the two grass species, Leptochloa fusca (L.) Stapf and Sporobolus robustus Kunth, under greenhouse conditions. African Journal of Biotechnology 14:2770-2776.

Fellbaum CR, Mensah JA, Cloos AJ, Strahan GE, Pfeffer PE, Kiers ET, ... Bucking H (2014). Fungal nutrient allocation in common mycorrhizal networks is regulated by the carbon source strength of individual host plants. New Phytologist 203:645-656. https://doi.org/10.1111/nph.12827

Gamage H K, Singhakumara B M, Ashton MS (2004). Effects of light and fertilization on arbuscular mycorrhizal colonization and growth of tropical rain-forest Syzygium tree seedlings. Journal of Tropical Ecology 20:525-534. https://doi.org/10.1017/S0266467404001592

Garmendia I, Mangas VJ (2012). Application of arbuscular mycorrhizal fungi on the production of cut flower roses under commercial-like conditions. Spanish Journal of Agricultural Research 1:166-174.

Gaur A, Adholeya A (2005). Diverse response of five ornamental plant species to mixed indigenous and single isolate arbuscular-mycorrhizal inocula in marginal soil amended with organic matter. Journal of Plant Nutrition 28:707723. https://doi.org/10.1081/PLN-200052647

Giovannetti M, Fortuna P, Citernesi AS, Morini S, Nuti MP (2001). The occurrence of anastomosis formation and nuclear exchange in intact arbuscular mycorrhizal networks. New Phytologist 151:717-724. https://doi.org/10.1046/j.0028-646x.2001.00216.x

Gonzalez-Chavez MC, Carrillo-Gonzalez R, Gutierrez-Castorena MC (2009). Natural attenuation in a slag heap contaminated with cadmium: The role of plants and arbuscular mycorrhizal fungi. Journal of Hazardous Materials 161:1288-1298. https://doi.org/10.1016/j.jhazmat.2008.04.110

González-Guerrero M, Azcón-Aguilar C, Mooney M, Valderas A, MacDiarmid CW, Eide DJ, Ferrol N (2005). Characterization of a Glomus intraradices gene encoding a putative $\mathrm{Zn}$ transporter of the cation diffusion facilitator family. Fungal Genetics and Biology 42:130-140. https://doi.org/10.1016/j.fgb.2004.10.007 
González-Guerrero M, Benabdellah K, Valderas A, Azcón-Aguilar C, Ferrol N (2010). GintABC1 encodes a putative $\mathrm{ABC}$ transporter of the MRP subfamily induced by $\mathrm{Cu}, \mathrm{Cd}$, and oxidative stress in Glomus intraradices. Mycorrhiza 20:137-146. https://doi.org/10.1007/s00572-009-0273-y

Hayashi M, Niwa R, Urashima Y, Suga Y, Sato S, Hirakawa H, ... Karasawa T (2018). Inoculum effect of arbuscular mycorrhizal fungi on soybeans grown in long-term bare-fallowed field with low phosphate availability. Soil Science and Plant Nutrition 64:306-311. https://doi.org/10.1080/00380768.2018.1473007

He JD, Dong T, Wu HH, Zou YN, Wu QS, Kuča K (2019). Mycorrhizas induce diverse responses of root TIPaquaporin gene expression to drought stress in trifoliate orange. Scientia Horticulturae 243:64-69. https://doi.org/10.1016/j.scienta.2018.08.010

He JD, Chi GG, Zou YN, Shu B, Wu QS, Srivastava AK, Kuča K (2020). Contribution of glomalin-related soil proteins to soil organic carbon in trifoliate orange. Applied Soil Ecology 154:103592. https://doi.org/10.1016/j.apsoil.2020.103592

Hishi T, Tateno R, Fukushima K, Fujimarki R, Itoh M, Tokuchi N, Näsholm T (2016). Changes in the anatomy, morphology and mycorrhizal infection of fine root systems of Cryptomeria japonica in relation to stand ageing. Tree Physiology 37:61-70. https://doi.org/10.1093/treephys/tpw076

Huang GM, Zou YN, Wu QS, Xu YJ, Kuča K (2020). Mycorrhizal roles in plant growth, gas exchange, root morphology, and nutrient uptake of walnuts. Plant, Soil and Environment 66:295-302. https://doi.org/10.17221/240/2020PSE

Ismail Y, Hijri M (2012). Arbuscular mycorrhisation with Glomus irregulare induces expression of potato PR homologues genes in response to infection by Fusarium sambucinum. Functional Plant Biology 39:236-245. https://doi.org/10.1071/fp11218

Jaiti F, Meddich A, El Hadrami I (2007). Effectiveness of arbuscular mycorrhizal fungi in the protection of date palm (Phoenix dactylifera L.) against bayoud disease. Physiological and Molecular Plant Pathology 71(4):166-173. https://doi.org/10.1016/j.pmpp.2008.01.002

Janoušková M, Pavlíková D (2010). Cadmium immobilization in the rhizosphere of arbuscular mycorrhizal plants by the fungal extraradical mycelium. Plant and Soil 332:511-520. https;//doi.org/10.1007/s11104-010-0317-2

Jin Z, Li J, Li Y (2015). Interactive effects of arbuscular mycorrhizal fungi and copper stress on flowering phenology and reproduction of Elsholtzia splendens. Plos One 10(12):e0145793. https://doi.org/10.1371/journal.pone.0145793

Joner E, Leyval C (2001). Time-course of heavy metal uptake in maize and clover as affected by root density and different mycorrhizal inoculation regimes. Biology and Fertility of Soils 33:351-357. https://doi.org/10.1007\%2Fs003740000331

Khalvait MA, Hu Y, Mozafar A, Schmidhalter U (2005). Quantification of water uptake by arbuscular mycorrhizal hyphae and its significance for leaf growth, water relations, and gas exchange of barley subjected to drought stress. Plant Biology 7:706-712. https://doi.org/10.1055/s-2005-872893

Kiers ET, Adler LS, Grman EL, Heijden MD (2010). Manipulating the jasmonate response: how do methyl jasmonate additions mediate characteristics of aboveground and belowground mutualisms? Functional Ecology 24:434-443. https://doi.org/10.1111/j.1365-2435.2009.01625.x

Klironomos J, Zobel M, Tibbett M, Stock WD, Rillig MC, Parrent JL (2011). Forces that structure plant communities: quantifying the importance of the mycorrhizal symbiosis. New Phytologist 189:366-370. https://doi.org/10.1111/j.1469-8137.2010.03550.x

Kumar A, Bhatti SK, Aggarwal A (2012). Biodiversity of endophytic mycorrhiza in some ornamental flowering plants of Solan, Himachal Pradesh. Biological Forum 4:45-51.

Kushwaha A, Rani R, Kumar S, Gautam A (2016). Heavy metal detoxification and tolerance mechanisms in plants: implications for phytoremediation. Environment Review 24:39-51. https://doi.org/10.1139/er-2015-0010

Lacombe S, Bradley R.L, Hamel C, Beaulieu C (2009). Do tree-based intercropping systems increase the diversity and stability of soil microbial communities? Agriculture Ecosystem and Environment 131:25-31. https://doi.org/10.1016/j.agee.2008.08.010

Lee EH, Eo JK, Ka KH, Eom A (2013). Diversity of arbuscular mycorrhizal fungi and their roles in ecosystems. Mycobiology 41(3):121-125. https://doi.org/10.5941/MYCO.2013.41.3.121

Leigh J, Hodge A, Fitter AH (2009). Arbuscular mycorrhizal fungi can transfer substantial amounts of nitrogen to their host plant from organic material. New Phytologist 181:199-207. https://doi.org/10.1111/j.14698137.2008.02630.x 
Li J, Meng B, Chai H, Yang XC, Song WZ, Li SX, ... Zhang T (2019). Arbuscular mycorrhizal fungi alleviate drought stress in C3 (Leymus chinensis) and C4 (Hemarthria altissima) grasses via altering antioxidant enzyme activities and photosynthesis. Frontiers in Plant Science 10:499. https://doi.org/10.3389/fpls.2019.00499

Li S, Yang W, Guo J, Li X, Lin J, Zhu X (2020). Changes in photosynthesis and respiratory metabolism of maize seedlings growing under low temperature stress may be regulated by arbuscular mycorrhizal fungi. Plant Physiology and Biochemistry 154:1-10. https://doi.org/10.1016/j.plaphy.2020.05.025

Li T, Hu Y, Hao Z, Li H. Wang YS. Chen BD (2013). First cloning and characterization of two functional aquaporin genes from an arbuscular mycorrhizal fungus Glomus intraradices. New Phytologist 197:617-630. https://doi.org/10.1111/nph.12011

Lin G, McCormack ML, Guo D (2015). Arbuscular mycorrhizal fungal effects on plant competition and community structure. Journal of Ecology 103:1224-1232. https://doi.org/10.1111/1365-2745.12429

Liu J, Maldonadomendoza IE, Lopezmeyer M, Cheung F, Town C, Harrison MJ (2007). Arbuscular mycorrhizal symbiosis is accompanied by local and systemic alterations in gene expression and an increase in disease resistance in the shoots. Plant Journal 50:529-544. https://doi.org/10.1111/j.1365-313X.2007.03069.x

Liu SJ, Guo HL, Xu J, Song ZY, Song SR, Tang JJ, Chen X (2018). Arbuscular mycorrhizal fungi differ in affecting the flowering of a host plant under two soil phosphorus conditions. Journal of Plant Ecology 11:623-631.

Majewska ML, Rola K, Zubek S (2017). The growth and phosphorus acquisition of invasive plants Rudbeckia laciniata and Solidago gigantea are enhanced by arbuscular mycorrhizal fungi. Mycorrhiza 27:83-94. https://doi.org/10.1007/s00572-016-0729-9

Marschner H, Dell B (1994). Nutrient uptake in mycorrhizal symbiosis. Plant and Soil 159:89-102. https://doi.org/10.1007/BF00000098

Mathur S, Jajoo A (2020). Arbuscular mycorrhizal fungi protect maize plants from high temperature stress by regulating photosystem II heterogeneity. Industrial Crops and Products 143:111934. https://doi.org/10.1016/j.indcrop.2019.111934

Mathur S, Sharma MP, Jajoo A (2018). Improved photosynthetic efficacy of maize (Zea mays) plants with arbuscular mycorrhizal fungi (AMF) under high temperature stress. Journal of Photochemistry and Photobiology 180:149154. https://doi.org/10.1016/j.jphotobiol.2018.02.002

Matsubara Y, Hirano I, Sassa D, Koshikawa K (2004). Alleviation of high temperature stress in strawberry plants infected with arbuscular mycorrhizal fungi. Environment Control in Biology 42:105-111.

Meng LL, He JD, Zou YN, Wu QS, Kuča K (2020). Mycorrhiza-released glomalin-related soil protein fractions contribute to soil total nitrogen in trifoliate orange. Plant, Soil and Environment 66:183-189. https://doi.org/10.17221/100/2020-PSE

Navarro A, Elia A, Conversa G, Campi P, Maetrorilli M (2012). Potted mycorrhizal carnation plants and saline stress: Growth, quality and nutritional plant responses. Scientia Horticulturae 140:131-139. https://doi.org/10.1016/j.scienta.2012.03.016

Perner H, Schwarz D, Bruns C, Mader P, George E (2007). Effect of arbuscular mycorrhizal colonization and two levels of compost supply on nutrient uptake and flowering of pelargonium plants. Mycorrhiza 17:469-474. https://doi.org/10.1007/s00572-007-0116-7

Policelli N, Bruns TD, Vilgalys R, Nuñez MA (2019). Suilloid fungi as global drivers of pine invasions. New Phytologist 222:714-725. https://doi.org/10.1111/nph.15660

Porcel R, Azcon R, Ruiz-Lozano JM (2004). Evaluation of the role of genes encoding for D1-pyrroline-5-carboxylate synthetase (P5CS) during drought stress in arbuscular mycorrhizal Glycine max and Lactuca sativa plants. Physiological and Molecular Plant Pathology 65:211-221. https://doi.org/10.1093/jxb/eri188

Powell JR, Rillig MC (2018). Biodiversity of arbuscular mycorrhizal fungi and ecosystem function. New Phytologist 220:1059-1075. https://doi.org/10.1111/nph.15119

Prados-Ligeo AM, Bascón-Fernandez J, Calvet-Pinós C, Ruiz AL, Melero-Vara JM, Jose BU (2002). Effect of different soil and clove treat-556 naqvi and naqviments in the control of white rot of garlic. Annals of Applied Biology 140:247-253. https://doi.org/10.1111/j.1744-7348.2002.tb00178.x

Rajtor M, Piotrowskaseget Z (2016). Prospects for arbuscular mycorrhizal fungi (AMF) to assist in phytoremediation of $\begin{array}{llll}\text { soil hydrocarbon } & \text { contaminants. }\end{array}$ https://doi.org/10.1016/j.chemosphere.2016.07.071 
Ratti N, Abdul K, Shukla PK (2000). Effect of Glomus mosseae (Nicol. and Gerd.) Gerdemann and Trappe on root-knot disease of menthol mint (Mentha arvensis spp. haplocalyx Briquet) caused by Meloidogyne incognita (Kofoid and White) Chitwood. Journal of Spices and Aromatic Crops 9:129-132.

Razem FA, Baron K, Hill RD (2006). Turning on gibberellin and abscisic acid signaling. Current Opinion in Plant Biology 9:454-459. https://doi.org/10.1016/j.pbi.2006.07.007

Rillig MC (2004). Arbuscular mycorrhizae and terrestrial ecosystem processes. Ecology Letters 7:740-754. https://doi.org/10.1111/j.1461-0248.2004.00620.x

Rillig MC, Mardatin NF, Leifheit EF, Antunes PM (2010). Mycelium of arbuscular mycorrhizal fungi increases soil water repellency and is sufficient to maintain water-stable soil aggregates. Soil Biology and Biochemistry 42:1189-1191. https://doi.org/10.1016/j.soilbio.2010.03.027

Augé RM, Toler HD, Sams CE, Nasim G (2008). Hydraulic conductance and water potential gradients in squash leaves showing mycorrhiza-induced increases in stomatal conductance. Mycorrhiza 18:115-121. Https://doi.org/10.1007/s00572-008-0162-9

Ruth B, Khalvati M, Schmidhalter U (2011). Quantification of mycorrhizal water uptake via high-resolution on-line water content sensors. Plant and Soil 342(1/2):459-468. https://doi.org/10.1007/s11104-010-0709-3

Sastry MS, Sharma AK, Johri BN (2000). Effect of an AM fungal consortium and Pseudomonas on the growth and nutrient uptake of Eucalyptus hybrid. Mycorrhiza 10:55-61. https://doi.org/10.1007/s005720000057

Scagel CF (2004). Inoculation with vesicular-arbuscular mycorrhizal fungi and rhizobacteria alters nutrient allocation and flowering of harlequin flower. HortTechnology 14:39-48. https://doi.org/10.21273/HORTTECH.14.1.0039

Shabani L, Sabzalian MR, Pour SM (2016). Arbuscular mycorrhiza affects nickel translocation and expression of ABC transporter and metallothionein genes in Festuca arundinacea. Mycorrhiza 26:67-76. https://doi.org/10.1007/s00572-015-0647-2

Shamshiri MH, Usha K, Singh B (2012). Growth and nutrient uptake responses of Kinnow to vesicular arbuscular mycorrhizae. Agronomy 4:689-693. https://doi.org/10.5402/2012/535846

Singer AC, Crowley DE, Thompson IP (2003). Secondary plant metabolites in phytoremediation and biotransformation. Trends in Biotechnology 21:123-130. https://doi.org/10.1016/S0167-7799(02)00041-0

Slezack S, Dumas-Gaudot E, Rosendahl S, Kjøller R, Paynot M, Negrel J, Gianinazzi S (1999). Endoproteolytic activities in pea roots inoculated with the arbuscular mycorrhizal fungus Glomus mosseae and/or Aphanomyces euteiches in relation to bioprotection. New Phytologist 142:517-529. https://doi.org/10.1046/j.1469-8137.1999.00421.x

Smith SE, Smith FA (2011). Roles of arbuscular mycorrhizas in plant nutritionand growth: new paradigms from cellular to ecosystem scales. Annual Review Plant of Biological 63:227-250. https://doi.org/10.1146/annurev-arplant042110-103846

Sohn BK, Kim KY, Chung SJ, Kim WS, Park SM, Kang JG, ... Lee JH (2003). Effect of different timing of AMF inoculation on plant and flower quality of chrysanthemum. Scientia Horticulture 98:173-183. https://doi.org/10.1016/S0304-4238(02)00210-8

Song F, Kong X, Dong A, Liu X (2012). Impact of arbuscular mycorrhizal fungi on the growth and related physiological indexes of Amorpha fruticosa. Journal of Medicinal Plants Research 6(20): 3648-3655. https://doi.org/10.5897/JMPR12.035

Stabler LB, Martin CA, Stutz JC (2001). Effect of urban expansion on arbuscular mycorrhizal fungal mediation of landscape tree growth. Journal of Arboriculture 27(4):193-202.

Sulzbacher MA, Grebenc T, Bevilacqua CB, Steffen RB, Coelho G, Silveira AO, ... Antoniolli ZI (2018). Co-invasion of ectomycorrhizal fungi in the Brazilian Pampa biome. Applied Soil Ecology 130:194-201. https://doi.org/10.1016/j.apsoil.2018.06.007

Swain SM, Singh DP (2005). Tall tales from sly dwarves: novel functions of gibberellins in plant development. Trends in Plant Science 10:123-129.

Teste FP, Kardol P, Turner BL, Wardle DA, Zemunik G, Renton M, Laliberté E (2017). Plant-soil feedback and the maintenance of diversity in Mediterranean-climate shrublands. Science 355:173-176. https://doi.org/10.1126/science.aai8291

Thorne ME, Rhodes L, Cardina J (2013). Soil compaction and arbuscular mycorrhizae affect seedling growth of three grasses. Open Journal of Ecology 3:455-463. https://doi.org/10.4236/oje.2013.37052

Tu JL, Liu XM, Xiao JX (2019). Effects of arbuscular mycorrhizal inoculation on osmoregulation and antioxidant responses of blueberry plants. Bangladesh Journal of Botany 48:641-647. 
Urcelay C, Diaz S (2003). The mycorrhizal dependence of subordinates determines the effect of arbuscular mycorrhizal fungi on plant diversity. Ecology Letters 6:388-391. https://doi.org/10.1046/j.1461-0248.2003.00444.x

Varga S, Kytöviita MM (2010). Gender dimorphism and mycorrhizal symbiosis affect floral visitors and reproductive output in Geranium sylvaticum. Functional Ecology 24:750-758. https://doi.org/10.1111/j.13652435.2010.01708.X

Varga S, Soulsbury CD (2017). Paternal arbuscular mycorrhizal fungal status affects DNA methylation in seeds. Biology Letters 13:1-4. https://doi.org/10.1098/rsbl.2017.0407

Vogelsang KM, Reynolds HL, Bever JD (2006). Mycorrhizal fungal identity and richness determine the diversity and productivity of a tall grass prairie system. New Phytologist 172:554-562. https://doi.org/10.1111/j.14698137.2006.01854.X

Wang J, Fu Z, Ren Q, Zhu LJ, Lin J, Zhang JC, ... Ma JY (2019a). Effects of arbuscular mycorrhizal fungi on growth, photosynthesis, and nutrient uptake of Zelkova serrata (Thunb.) makino seedlings under salt stress. Forests 10:186-206. https://doi.org/10.3390/f10020186

Wang J, Wang GG, Zhang B, Zhang B, Yuan ZM (2019b). Arbuscular mycorrhizal fungi associated with tree species in a planted forest of eastern China. Forests 10:424-436. https://doi.org/10.3390/f10050424

Wang S, Chen A, Xie K, Yang XF, Luo ZZ, Chen JD, ... Xu GH (2020). Functional analysis of the OsNPF4.5 nitrate transporter reveals a conserved mycorrhizal pathway of nitrogen acquisition in plants. Proceedings of the National Academy of Sciences 117:16649-16659. https://doi.org/10.1073/pnas.2000926117

Wang YY, Vestberg M, Walker C, Hurme T, Zhang XP, Lindstrom K (2008). Diversity and infectivity of arbuscular mycorrhizal fungi in agricultural soils of the Sichuan Province of mainland China. Mycorrhiza 18:59-68. https://doi.org/10.1007/s00572-008-0161-X

Watts-Williams SJ, Cavagnaro TR, Tyerman SD (2019). Variable effects of arbuscular mycorrhizal fungal inoculation on physiological and molecular measures of root and stomatal conductance of diverse Medicago truncatula accessions. Plant Cell \& Environment 42:285-294. https://doi.org/10.1111/pce.13369

Werner GDA, Kiers ET (2015). Partner selection in the mycorrhizal mutualism. New Phytologist 205:1437-1442. https://doi.org/10.1111/nph.13113

Wiseman PE, Wells C (2005). Soil inoculum potential and arbuscular mycorrhizal colonization of Acer rubrum in forested and developed landscapes. Journal of Arboriculture 31:296-302.

Wu QS, He JD, Srivastava AK, Zou YN, Kuča K (2019). Mycorrhizas enhance drought tolerance of citrus by altering root fatty acid compositions and their saturation levels. Tree Physiology 39:1149-1158. https://doi.org/10.1093/treephys/tpz039

Wu QS, Srivastava AK, Zou YN (2013). AMF-induced tolerance to drought stress in citrus: A review. Scientia Horticulturae 164:77-87. https://doi.org/10.1016/j.scienta.2013.09.010

Xie MM, Wu QS (2015). Mycorrhiza modulates morphology, color and duration of flowers in hyacinth. Biotechnology 16:116-122. https://doi.org/10.3923/biotech.2017.116.122

Xie MM, Wu QS (2018). Arbuscular mycorrhizal fungi regulate flowering of Hyacinths orientalis L. Anna marie. Emirates Journal of Food and Agriculture 30:144-149. https://doi.org/10.9755/ejfa.2018.v30.i2.1614

Xie MM, Zou YN, Wu QS, Zhang ZZ, Kuča K (2020). Single or dual inoculation of arbuscular mycorrhizal fungi and rhizobia regulates plant growth and nitrogen acquisition in white clover. Plant, Soil and Environment 66:287-294. Https://doi.org/10.17221/234/2020-PSE

Yang AN, Lu L, Wu CX, Xia MM (2011). Arbuscular mycorrhizal fungi associated with Huangshan Magnolia (Magnolia cylindrica). Journal of Medicinal Plants Research 5:4542-4548. https://doi.org/10.5897/JMPR.9000262

Yang G, Yang X, Zhang W, Wei Y, Ge G, Lu W, ... Zhang YJ (2016a). Arbuscular mycorrhizal fungi affect plant community structure under various nutrient conditions and stabilize the community productivity. Oikos 125:576-585. https://doi.org/10.1111/oik.02351

Yang R, Zhou G, Zan S, Guo F, Su N, Li J (2014a). Arbuscular mycorrhizal fungi facilitate the invasion of Solidago canadensis L. in southeastern China. Acta Oecological 61:71-77. https://doi.org/10.1016/j.actao.2014.10.008

Yang Y, Han X, Liang Y, Ghosh A, Chen J, Tang M (2015a). The combined effects of arbuscular mycorrhizal fungi (AMF) and lead $(\mathrm{Pb})$ stress on $\mathrm{Pb}$ accumulation, plant growth parameters, photosynthesis, and antioxidant enzymes in Robinia pseudoacacia L. PLoS ONE 10:e145726. https://doi.org/10.1371/journal.pone.0145726

Yang Y, Liang Y, Ghosh A, Song YY, Chen H, Tang M (2015b). Assessment of arbuscular mycorrhizal fungi status and heavy metal accumulation characteristics of tree species in a lead-zinc mine area: potential applications for 
Xie M-M et al. (2020). Not Bot Horti Agrobo 48(3):1100-1115

phytoremediation. Environmental Science and Pollution Research 22:13179-13193. https://doi.org/10.1007/s11356-015-4521-8

Yang Y, Liang Y, Han XZ, Chiu TY, Ghosh A, Chen H, Tang M (2016b). The roles of arbuscular mycorrhizal fungi (AMF) in phytoremediation and tree-herb interactions in Pb contaminated soil. Scientific Reports 6:20469. https://doi.org/10.1038/srep20469

Yang YR, Tang M, Sulpice R, Chen H, Tian S, Ban YH (2014b). Arbuscular mycorrhizal fungi alter fractal dimension characteristics of Robinia pseudoacacia L. seedlings through regulating plant growth, leaf water status, photosynthesis, and nutrient concentration under drought stress. Journal of Plant Growth Regulation 33:612625. https://doi.org/10.1007/s00344-013-9410-0

Zhang F, Liu M, Li Y, Chen YY, Xiao Y (2019a). Effects of arbuscular mycorrhizal fungi, biochar and cadmium on the yield and element uptake of Medicago sativa. Science of The Total Environment 655:1150-1158. https://doi.org/10.1016/j.scitotenv.2018.11.317

Zhang F, Zou YN, Wu QS (2018a). Quantitative estimation of water uptake by mycorrhizal extraradical hyphae in citrus under drought stress. Scientia Horticulturae 229:132-136.

Zhang F, Zou YN, Wu QS, Kuča K (2020). Arbuscular mycorrhizas modulate root polyamine metabolism to enhance drought tolerance of trifoliate orange. Environmental and Experimental Botany 171:103962. https://doi.org/10.1016/j.envexpbot.2019.103926

Zhang Y, Hu J, Bai J, Wang JH, Yin R, Wang JW, Lin X (2018b). Arbuscular mycorrhizal fungi alleviate the heavy metal toxicity on sunflower (Helianthus annuus L.) plants cultivated on a heavily contaminated field soil at a WEEErecycling site. Science of The Total Environment 628:282-290. https://doi.org/10.1016/j.scitotenv.2018.01.331

Zhang YC, Zou YN, Liu LP, Wu QS (2019b). Common mycorrhizal networks activate salicylic acid defense responses of trifoliate orange (Poncirus trifoliata). Journal of Integrative Plant Biology 61:1099-1111. https://doi.org/10.1111/jipb.12743

Zhou X, Fu L, Xia Y, Zheng LQ, Chen C, Shen ZG, Chen YH (2017). Arbuscular mycorrhizal fungi enhance the copper tolerance of Tagetes patula through the sorption and barrier mechanisms of intraradical hyphae. Metallomics 9:936-948. https://doi.org/10.1039/C7MT00072C

Zhu XC, Song FB, Liu SQ, Liu TD, Zhou X (2012). Arbuscular mycorrhizae improve photosynthesis and water status of Zea mays L. under drought stress. Plant Soil and Environment 58:186-191. https://doi.org/10.17221/23/2011PSE

Zou YN, Wu HH, Giri B, Wu QS, Kuca K (2019). Mycorrhizal symbiosis down-regulates or does not change root aquaporin expression in trifoliate orange under drought stress. Plant Physiology and Biochemistry 144:292-299. https://doi.org/10.1016/j.plaphy.2019.10.001

Zou YN, Wu QS, Kuča K (2020). Unraveling the role of arbuscular mycorrhizal fungi in mitigating the oxidative burst of plants under drought stress. Plant Biology https://doi.org/10.1111/plb.13161
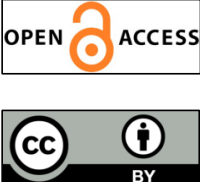

The journal offers free, immediate, and unrestricted access to peer-reviewed research and scholarly work. Users are allowed to read, download, copy, distribute, print, search, or link to the full texts of the articles, or use them for any other lawful purpose, without asking prior permission from the publisher or the author.

License - Articles published in Notulae Botanicae Horti Agrobotanici Cluj-Napoca are Open-Access, distributed under the terms and conditions of the Creative Commons Attribution (CC BY 4.0) License. (c) Articles by the authors; UASVM, Cluj-Napoca, Romania. The journal allows the author(s) to hold the copyright/to retain publishing rights without restriction. 